\title{
ONLINE FÓKUSZCSOPORTOK ALKALMAZÁSA - LEHETŐSÉGEK, KORLÁTOK ÉS TANÁCSOK A HATÉKONYSÁG NÖVELÉSÉRE
}

Az utóbbi évtizedekben a fókuszcsoportos módszernek számos, különböző online változata jelent meg. Ide tartoznak a szövegalapú csoportok, ahol a résztvevők begépelik válaszaikat, a videós fókuszcsoportok, ahol látják és hallják is egymást, valamint a 3D virtuális, grafikus környezetben zajló fókuszcsoportok. A cikkben a szerző először a különböző online fókuszcsoport-típusokat mutatja be, majd a szövegalapú online fókuszcsoportokat középpontba állítva ezek előnyeit és hátrányait elemzi az offline csoportokhoz, valamint a többi internetes csoporttípushoz képest. Amellett érvel, hogy a szöveges kommunikációt tartalmazó csoportoknak számos praktikus előnyük van; és még manapság amikor videós fókuszesoportokra is sor kerülhet, érdemes alkalmazni őket. Ugyanakkor nagyon oda kell figyelni arra, hogy hogyan történik az ilyen virtuális fókuszcsoport kivitelezése, mert nem megfelelő kialakítás esetén a kapott eredmények túl szegényesek lehetnek. A cikk tárgyal számos olyan opciót, amelyeket alkalmazva egy-egy gépelt csoport hatékonysága növelhető. Ezeken felül kitér arra is, hogy a teljesebb kép kialakítása érdekében hasznosnak bizonyulhat egy kutatás során mind szinkron, mind aszinkron begépelös fókuszcsoportokat alkalmazni. A szövegesen is zajló csoportokat érdemes lehet gazdagítani fotó- és videófeltöltési lehetőségek kel is. Megfontolandó az is, hogy az online kvalitatív kutatási lehetőségek még jobban kiaknázhatók, ha kihasználják a közösségi oldalakat is az adatgyüjtéshez és a lebonyolításhoz, valamint, ha az online fókuszcsoportokat kombinálják egyéb online kutatási módszerekkel - akár egy netnográfiai projekt keretein belül. ${ }^{1}$

\section{Kulcsszavak: online fókuszcsoportok, szövegalapú fókuszcsoport, online kvalitatív kutatás}

A fókuszcsoportok alapesetben olyan csoportos interjúkat/beszélgetéseket jelentettek, amelyek egy kutatási téma köré fókuszáltak és egy moderátor vezetésével zajlottak. Amikor a módszernek megjelentek az online változatai, amelyekben számítógépen keresztül kommunikálnak a csoporttagok, akkor voltak olyan várakozások, hogy esetleg majd hangsúlyos szerepük lesz a kvalitatív kutatások között. Ehhez képest Graffigna és Bosio egy 2006-os írásukban amellett érveltek, hogy az online fókuszcsoport módszere a tudományos közösségben kevéssé használatos a kvalitatív egészségügyi kutatások kivételével. Ha a tudományos írásokat gyüjtő Google Scholar segítségével keresünk online fókuszcsoport-módszert alkalmazó kutatást, látható, hogy ez a helyzet azóta sem változott lényegesen ${ }^{2}$. Alapkutatási célra tehát nem lett népszerü eszköz az online fókuszcsoport, és vannak arra utaló jelek, hogy a piackutatási reményeket sem váltotta be. ${ }^{3}$

A nagy sávszélességi igénye, a webkamera szükségessége korlátozó tényezők a videós fókuszcsoportok terjedésében. Bár folyamatosan fejlődnek a videós csetelési lehetőségek, nő a megfelelő sávszélességgel, webkamerával rendelkezők aránya és így a videós fókuszcsoportok tartásának lehetőségei is javulnak, még a fejlett országokban is a lakosság jelentős szegmensei nem elérhetők ezzel a módszerrel (Link - Dinsmore, 2014).

$\mathrm{Az}$ online begépelós fókuszcsoportokkal jelenleg ennél szélesebb társadalmi rétegeket lehet elérni, ráadásul egyszerübb, gyorsabb és olcsóbb a lebonyolítása (pl. nincs szükség az átirat legépelésére, hiszen rögtön rendelkezésre áll stb.). Az anonimitás hatásait is kiaknázhatjuk, amennyiben nem azonosítják be magukat egymás számára a résztvevők. A fenti előnyös tulajdonságok ellenére mégsem tudott divatossá válni a szövegalapú fókuszcsoport. Úgy gondolom, ennek a begépeléses verziónak az egyik fontos terjedési korlátját az adatgazdagsági problémák jelentik. A Piackutatás blog körkérdésére válaszolva 2010-ben több magyar piackutató szintén említi az adatgazdagság problémáját, mint az egyik ok, ami hozzájárulhatott ahhoz, hogy nem használják a jelenleginél szélesebb 
körben a módszert (Forecast Research, 2010b). Ugyanakkor több hazai és külföldi szakértővel egyetértve úgy vélem, hogy megfelelő célra történő használat során és jó kivitelezéssel ezek a csoportok is sok hasznos inputot adhatnak (Graffigna - Bosio, 2006; Underhill - Olmsted, 2003). Bizonyos szervezési és kivitelezési megoldások segíthetik a szövegalapú csoportok eredményességét és javíthatják az adatgazdagságot.

A cikkben amellett érvelek, hogy továbbra is érdemes megfontolni a szövegalapú fókuszcsoport alkalmazását annak ellenére is, hogy napjainkban az online videós beszélgetés lehetősége is egyre könnyebben elérhetővé válik. Elsőként részletesen tárgyalom a különböző online fókuszcsoport-típusokat. Ezt követően a szövegalapú fókuszcsoportokat helyezem a középpontba: ezek előnyeinek és hátrányainak bemutatását követően a cikkben azt vizsgálom, hogyan lehet javítani az így kapott adatok minőségét, valamint gyakorlati tanácsokat fogalmazok meg kutatók számára a módszer nyújtotta lehetőségek kiaknázásához. Érvelésemben a vonatkozó irodalom áttekintésén túl, saját kutatói tapasztalataimra is építek, valamint felhasználom különféle alkalmazott és alapkutatásokban részt vevö fókuszcsoportos szakemberekkel folytatott beszélgetéseimet is.

\section{Online fókuszcsoport-változatok}

A kommunikációs mód alapján többféle online fókuszcsoport -típust különböztethetünk meg. Ezek közé tartoznak a szövegalapú csoportok, ahol begépelik válaszaikat a résztvevők, és a videós fókuszcsoportok, ahol látják és hallják is egymást (Link - Dinsmore, 2014). Léteznek különféle kombinált verziók is: például elöfordul olyan megoldás, ahol amellett, hogy alapvetően begépelik válaszaikat a résztvevők, fotókat és videókat is feltölthetnek. Ritkán, de találkozhatunk 3D virtuális, grafikus környezetben zajló fókuszcsoportokkal is. Ezek lehetővé teszik, hogy a résztvevőket grafikus reprezentációk - avatarok - személyesítsék meg. A résztvevők személyre szabhatják az avataruk kinézetét egy listából, amely rengeteg lehetóséget tartalmaz. A résztvevők navigálhatják és mozgathatják is az avatarjaikat a virtuális környezeten belül. A kutatók megszabhatják a helyszínt, választhatnak egy olyan vizuális megjelenítést, amely szerintük a kutatási témához, csoportöszszetételhez megfelelő lehet. Például a Secondlife ${ }^{4}$ fejlesztői a fókuszcsoportok tartása számára létrehoztak egy virtuális épületet, amelynek termei hasonlítanak a tradicionális fókuszcsoportok környezetéhez (Tatar, 2008). Talán elsőre furcsának tủnhet ez a fókuszcsoport-szervezési opció, ugyanakkor egy pusztán audiocsoporthoz képest több előnye is van. Egyes platformok olyanok, hogy megkülönböztethetö, hogy éppen ki be- szél (az avatar szája akkor mozog), metakommunikációs jeleket is tudnak adni az avatarok (pl. fejrázás, ha valamivel nem értenek egyet stb.). Stewart és Williams (2005) szerint további előny, hogy van egy helyszín, amihez kapcsolódhatnak a résztvevők, még ha virtuális is - így jobban részt vehetnek a beszélgetésben. Ez a fajta csoportos beszélgetés vizuálisan is leköti a résztvevőket és így kevésbé valószínü, hogy esetleg mást kezdenek nézni a számítógépen, mintha csak hang alapján kommunikálnának, de nem lenne semmilyen vizuális megjelenítés. Találhatunk több példát is a fókuszcsoportos szakirodalmak között, amikor ilyen fókuszcsoportokat alkalmaztak. Például Hetzel (2014) kortársbántalmazásban érintett fiatalokkal készített fókuszcsoportot, itt jól jött számára, hogy a módszer lehetővé teszi az anonimitást a résztvevők között. Készült kutatás a virtuális közösségekben történő bünözés és ennek szabályozása kapcsán is. Utóbbi vizsgálat során nem hanggal, hanem gépeléssel kommunikáltak a résztvevők, amellett, hogy vizuálisan kifejezhettek reakciókat avatarjaik segítségével (Williams, 2007).

Az online csoportok különbözhetnek időbeliségben is. Szinkron fókuszcsoport esetén a résztvevők egyidejüleg vannak jelen a csoportban, míg aszinkron csoportok esetében ez nem feltétlenül van így (Burton - Goldsmith, 2002; Rezabek, 2000). A szinkron szövegalapú fókuszcsoport az online csevegés (chat) egy speciális formája. Az különbözteti meg a mindennapi online csevegéstől, hogy a beszélgetést ebben az esetben egy moderátor vezeti kutatási céllal. Az aszinkron szöveges fókuszcsoportok formátuma egy online üzenőfalhoz vagy fórumhoz hasonlít, jellemzően hosszabb ideig tart, a résztvevők pedig nincsenek egyidejüleg jelen (Cook - Jack - Siden - Thabane - Browne, 2014; Taylor - MacDonald, 2002; Walston - Lissitz, 2000). A hétköznapi fórumtól ebben az esetben is az különbözteti meg a csoportot, hogy a beszélgetést moderátor vezeti kutatási céllal, és a beszélgetés hosszúságát is ő szabja meg. Egy aszinkron csoport tarthat néhány napig vagy hétig, egyes esetekben akár hosszabb ideig is.

A hozzászólások különbözőek lehetnek a két gépelt formátum esetében: Graffigna és Bosio (2006) úgy találták, hogy az aszinkron csoportok résztvevői átgondoltabb, racionálisabb érveket sorakoztattak fel, a hozzászólások hosszabbak voltak, és kevesebb volt az interakció, mint a szinkron fókuszcsoportok esetében. Csevegő helyzetben jellemzőbbek voltak a spontán válaszok és az érzelmi reakciók. A kutatók szerint ez egyfajta közös ötleteléshez (brainstorming) hasonlítható, ahol számos gondolat felmerül, ám nincs tér ezek kibontására. Ebben a helyzetben a beszélgetés nem feltétlenül folyik lineáris mederben: ha a moderátor új kérdést tesz fel, a válaszolók még mindig reagálhatnak a korábbi témákra is. Szinkron és aszinkron fókusz- 
csoportos kutatások konkrét példáit részletesen tárgyalom fókuszcsoportos szakkönyvemben (Vicsek, 2006).

Egyes kutatók megkérdőjelezik, hogy az aszinkron szövegalapú társalgások csoporthelyzetnek tekinthetők-e egyáltalán, hiszen lényegesen eltérő dinamika és a közvetlenség hiánya jellemzi őket (Fox - Morris Rumsey, 2007).

A csak videót alkalmazó fókuszcsoportok lényegében mindig szinkron csoportok, vannak viszont olyan kombinált típusok, ahol videókat is alkalmaznak és szövegeket is, és aszinkron módon kerül rájuk sor. Ekkor a szövegek begépelése mellett a résztvevők akár videót is feltölthetnek. Egyik módja ennek, amikor pl. a Youtube-ra töltenek fel videókat, és a többiek kommentelhetik ezeket a videók alatt.

A fókuszcsoportok eltérhetnek a biztosított anonimitás szerint is, illetve, hogy mennyi információt tudnak egymásról a résztvevők. Az online beszélgetések egyes változataiban a résztvevők nem láthatják egymást, az anonimitás szintje ilyenkor azon múlik, hogy milyen információk állnak rendelkezésre a többi résztvevőről: tudják-e, hogy kik vesznek részt a csoportban, ismerik-e a többiek korát, nemét stb.? Az anonimitás a kutatók felé is fennállhat: változhat, hogy pontosan tudják-e, melyik felhasználónév, melyik résztvevőt takarja, vagy csak a résztvevők körét ismerik, de azt nem, hogy melyik hozzászólás kitől származik?

További különbség, hogy milyen eszközökröl kapcsolódhatnak be a résztvevök a csoportba: pl. számítógép, tablet vagy mobiltelefon.

A csoportos beszélgetések a szerint is megkülönböztethetők, hogy milyen platformon zajlanak: ingyen hozzáférhetö felületen - pl. chatszobában (Schneider et al., 2002), GoogleHangouts-on, Skype-on stb. -, vagy olyan speciális szoftver felhasználásával, amelyet kifejezetten online fókuszcsoportok lebonyolítására fejlesztettek ki (Franklin - Lowry, 2001), esetleg fizetös videókonferencia-oldalon.

A kifejezetten fókuszcsoportok levezetésére tervezett professzionális platformok az ingyenesen hozzáférhető lehetőségekhez képest extra szolgáltatásokat is nyújtanak. Többek között: megjelenítik a résztvevők információit (társadalmi, demográfiai adatok), megkönnyítik a moderátor és a megbízó közötti kapcsolattartást, az utóbbi ugyanis menet közben kérheti további kérdések beemelését a csoportos beszélgetésbe. Ezen felül a moderátor máshogy jelenik meg, mint a résztvevők a videós verziónál, a szöveges verziónál egyértelmüen megkülönböztethető, hogy mit írt a moderátor, és mit az egyes résztvevők (pl. különböző betűszínnel). Professzionális platformok esetében könnyen használhatók a társalgást inspiráló anyagok, vetítési módszerek, speciális technikák. Az ingyenes csevegőfelületek mindazonáltal kifejezetten hasznosak lehetnek, ha a kutató nem megrendelésre dolgozik, hanem saját nonprofit vizsgálatot folytat. (Ebben az esetben is megoldható, hogy a moderátor hozzászólásai egyértelmüen megkülönböztethetők legyenek a csoporttagokétól. Ha a használt program nem teszi lehetővé a különböző betúszíneket, a moderátornak érdemes lehet például csupa nagybetủvel írnia.)

Egy újabb fejlemény az online fókuszcsoportok alkalmazásában a virtuális csoportok létrehozásával közösségi (social network) oldalakon zajló vizsgálatok. Lijadi és Schalkwyk (2015) kutatásukban például online Facebook-fókuszcsoportokat alkalmaztak. Vizsgálatuk során olyan fiatalokkal akartak fókuszcsoportokat készíteni, akik több országban is éltek gyerekkorukban. A kutatók olyan nyílt Facebook-csoportokba írtak, amelyek tagjai több kultúrában élő személyek voltak, és onnan egyszerüen tudtak toborozni kutatási alanyokat saját vizsgálatukhoz, ahol is zárt Facebookcsoportok keretében kérdezték le őket.

\section{A szövegalapú csoportok előnyei}

Az online szövegalapú fókuszcsoport számos gyakorlati elönnyel és erősséggel rendelkezik.

Gyors, így időt takarítunk meg vele. Különösen abban az esetben gyors, amikor a kutató szinkron adatgyüjtési módszert használ. Kvalitatív kutatás esetén gyakran fontos, hogy írásban is rögzítsük az interjún vagy csoportos beszélgetésen elhangzottakat. A szövegalapú fókuszcsoport esetén az azonnal létrejövö átirat meggyorsítja a kutatás folyamatát (Franklin Lowry, 2001; Walston - Lissitz, 2000). Ha a kutatási célnak az egyéni interjú és az online fókuszcsoportos beszélgetés egyaránt megfelel, gyorsabb és egyszerübb, ha hat hasonló tulajdonságokkal bíró alannyal szervezünk csoportos beszélgetést, mint ha külön-külön interjúznánk ugyanazzal a hat személlyel. Szintén időt takarít meg, hogy a kutatónak nem szükséges utaznia, mint offline esetben.

A szövegalapú fókuszcsoport emellett költségkimélö is. Olcsóbb, mint a személyes jelenlétet igénylő vagy az online videós fókuszcsoport, mivel a szoba bérlése, az üdítő vagy harapnivaló biztosítása, a begépelés, a videó rögzítése, valamint az odautazás nem igényel külön forrást. Ez a módszer különösen költségkímélő akkor, ha a kutató nem speciálisan fókuszcsoportok tartására kifejlesztett fizetős szoftvert alkalmaz. Egyes szerzők szerint azonban még az erre kifejlesztett fizetôs alkalmazás használatakor is olcsóbb az online szöveges fókuszcsoport, mint a személyes jelenlétet igénylő módszer (Newby - Soutar - Watson, 2003). A csoport résztvevői sokszor anyagi kompenzáció fejében vállalkoznak a részvételre. Online csoportos társalgásba azonban akár az otthonukból is bekapcsolódhatnak, és mivel a 
részvétel így kisebb erőfeszítést igényel, egyes szerzők szerint alacsonyabb összeg fejében is bevonhatók (Maulana, 2002), illetve könnyebben elérhető, hogy pénzbeli ösztönző nélkül is részt vegyenek a csoportban. Magam is számos, teljesen ingyenes társadalomtudományos célzatú fókuszcsoportot vezettem le sikeresen: ingyenesen hozzáférhető csevegőprogramot használtunk, a résztvevők pedig nem igényelték a pénzbeli motivációt (egyéb okokból is érdekeltek voltak a részvételben, például érdekelte öket a kutatási téma).

A szövegalapú fókuszcsoport segítségével megvan a lehetőség, hogy a kutató úgy gyüjtsön információt, hogy a résztvevők anonimek maradnak. Egyes résztvevők nyiltabban írhatnak bizonyos témákról akkor, ha a többi résztvevő nem ismeri a kilétüket, így könnyebben vállalhatják a részvételt, mint ha felismerhetők lennének a többi résztvevő számára. Szintén könnyebben vonhatók be olyan alanyok, akik a megjelenésükkel kapcsolatos problémák - például krónikus bőrbetegség - miatt szívesebben maradnak láthatatlanok (Fox et al., 2007). Az arctalanság bizonyos esetekben elösegítheti, hogy a résztvevők érzékeny témákkal kapcsolatban is bátrabban megnyilvánuljanak (Graffigna - Bosio, 2006). A fókuszcsoportos módszert alkalmazó kutatók egy része azzal érvel, hogy anonim online szövegalapú csoport esetén kevésbé érvényesül a csoportnyomás, illetve alacsonyabb a konformitás szintje, mint a személyes jelenlétet igénylő beszélgetések esetén, így a vélemények és gondolatok szélesebb köre kerül terítékre, illetve a résztvevők bátrabban vállalják kisebbségben lévő véleményüket is (Ho - McLeod, 2008; Síklaki, 2006; Taylor - MacDonald, 2002). Empirikus adatok támasztják alá azt az érvelést is, amely szerint a résztvevők inkább felvállalják a társadalmilag elitélt viselkedést az anonim szövegalapú csoportban, miközben a társadalmi elvárások nagyobb szerepet játszanak a szemtől szembeni beszélgetésekben, így az anonim online módszer a kutatónak való megfelelni akarást is csökkentheti (Graffigna - Bosio, 2006; Walston Lissitz, 2000). Az anonimitás mellett az is erősíti a többségi véleménytől eltérő válaszok adását, hogy a résztvevők időnként egyszerre gépelik be hozzászólásaikat. Ilyenkor csak azután látják a másik csoporttag válaszát, amikor már elküldték a saját hozzászólásukat (Newby - Soutar - Watson, 2003), így a párhuzamosan megírt eltérő vélemény nem befolyásolja a hozzászólást. Síklaki úgy érvel: "A csoport résztvevői a saját környezetükben, a saját képernyőjük és billentyüzetük elött sokkal nagyobb mértékben képesek megörizni egyéni szuverenitásukat" (Index, 2006).

Arra is utalnak jelek, hogy a személyes jelenléten alapuló csoportokhoz képest az online szövegalapú csoportokban kevésbé jellemzö, hogy néhány asszertívabb hangadó dominálja a vitát (Franklin - Lowry,
2001; Newby - Soutar - Watson, 2003; Schneider et al., 2002; Taylor - MacDonald, 2002; Walston - Lissitz, 2000). Ez részben az egymásról szerzett vizuális információ hiányának is köszönhető. A karizmatikus, magasabb státusú résztvevők dominanciája ugyanis bizonyos esetekben a megjelenésüknek köszönhető: annak, ahogy kinéznek és öltözködnek, a beszédstílusuknak, hangvételüknek és a nonverbális kommunikációjuknak (Walston - Lissitz, 2000). A dominanciánál szintén fontos tényező, hogy bár egyes résztvevők kifejezetten sokat írnak, ez nem akadályozza meg a többieket abban, hogy párhuzamosan kommunikáljanak, hiszen egyidejüleg begépelhetik a saját hozzászólásaikat. A domináns hozzászóló tehát technikai szempontból sem gátolja a többiek részvételét.

A csoporttagoknak nem kell megjelenniük egy adott helyszínen, ehelyett kényelmesen, a saját otthonukban is be tudnak kapcsolódni (Bodoky, 2007). Ez fontos lehet azoknak, akik számára a közlekedés problémát jelent - például bizonyos átmeneti vagy akár tartós egészségügyi problémával élőknek (Cook et al., 2014; Turney - Pocknee, 2005), vagy szülői kíséretet igénylő fiataloknak, gyerekeknek (Nicholas et al., 2010).

Online fókuszcsoport szervezésével összeköthetők különböző városokban, régiókban, vagy akár más-más országban élő résztvevők, így földrajzilag szétszórt csoporttagok is bevonhatók.

Ahogy egyre többen használják az internetet, egyre több ember érhető el online, így a tagok bevonását és a szervezést egyszerüsitheti, ha interneten toborzunk, és online tartjuk meg a csoportot.

Ha online jelenséget vizsgálunk, különösen alkalmas lehet ez az eszköz, mivel a mérési módszer hasonlit a kutatási terület természetes közegére (Gaiser, 1997). Az ilyen csoportok egyes szerzők szerint különösen alkalmasak online weboldalakkal kapcsolatos vélemények tesztelésére, mivel a csoport tagjai a beszélgetés alatt meg tudják nyitni a kérdéses oldalakat (Herendy, 2009; Maulana, 2002; Schneider et al., 2002).

A szövegalapú csoport megszervezése ezen felül kevesebb technikai tudást igényel a felhasználóktól, mint az online videós csoportok. Az utóbbihoz szükséges technikai feltételek számos társadalomban még mindig kihívást jelentenek a potenciális résztvevők egy része számára, mivel a populáció egy része egyszerúen nem rendelkezik jó minőségü webkamerás bekapcsolódást lehetővé tévő gyors internetkapcsolattal (Link - Dinsmore, 2014).

$\mathrm{Az}$ aszinkron csoportok esetében sokszor hasznos az a rugalmasság, hogy a résztvevők akár egy napos csúszással is reagálhatnak egy-egy kérdésre (Turney Pocknee, 2005).

Egy félénkebb résztvevö számára komoly könynyebbséget jelenthet, ha személyes részvétel helyett 
szövegalapú fókuszcsoportba kapcsolódhat be. Egy online szövegalapú csoportot levezető diákom arról számolt be, hogy szemtől szembeni csoport moderálására valószínüleg nem mert volna vállalkozni, hiszen ő maga is túlságosan félénk, a szövegalapú társalgási helyzet azonban nem feszélyezte.

Egyes esetekben pedig az is hasznos lehet, ha egynél több moderátor vezeti a beszélgetést, akik támogatják egymás munkáját, és akár ugyanabban a helyiségben is tartózkodhatnak a csoport időtartama alatt (Walston - Lissitz, 2000). Ez könnyen megvalósítható szövegalapú fókuszcsoport esetén.

\section{Lehetséges problémák}

Előfordulhat, hogy az online szövegalapú fókuszcsoport kevésbé gazdag és mély elemzést tesz lehetővé, mint a személyes találkozás vagy az online videós csoportbeszélgetés. Ezt a problémát a fókuszcsoportok módszertanáról szóló irodalom is tárgyalja (Abrams et al., 2015; Newby - Soutar - Watson, 2003; Schneider et al., 2002). Saját tapasztalataim szerint is a módszer legnagyobb kihívása az adatgazdagság biztosítása.

A szövegalapú fókuszcsoportot a személyes jelenléten alapuló módszerrel összehasonlító empirikus elemzések arra a következtetésre jutottak, hogy a szövegalapú módszer esetén a kapott információk kevésbé mélyek, és nehézkesebb a kommunikáció követése (Abrams - Wang - Song - Galindo-Gonzalez, 2015; Franklin - Lowry, 2001; Grady, 2000; Newby - Soutar - Watson, 2003; Schneider - Kerwin - Frechtling - Vivari, 2002).

Empirikus adatok szerint az online videós fókuszcsoport szervezésével nagyobb adatgazdagság érhető el, mint a szövegalapú csoporttal. Abrahams és munkatársai (2015) közelmúltbéli kutatásukban például úgy találták, hogy az online webkamerás fókuszcsoport adatgazdagság terén közel áll a személyes találkozáson alapuló csoporthoz, míg az azonos ideig tartó szövegalapú csoport gyengébben teljesített (az adatgazdaságot több különböző mutató mentén értékelték, mint például a rögzített szavak száma, vagy a kutatók szubjektív megítélése).

Számos tényező veszélyeztetheti a szinkron online csoport során gyüjtött adatok gazdagságát és mélységét. A válaszok gyakran rövidebbek, a kijelölt témát a résztvevők kevésbé részletesen vitatják meg, és számos résztvevő kisebb részletességgel indokolja meg a véleményét (Franklin - Lowry, 2001; Grady, 2000; Schneider et al., 2002). A moderátor számára nehezebb spontán módon rákérdezni egy írott hozzászólásra ami pedig elmélyíthetné a társalgást. Az adatminőséget veszélyeztethetik a párhuzamosan futó gondolatmenetek (,threading”): előfordulhat, hogy egyes résztvevők még egy korábbi kérdésre reagálnak, míg mások már egy újabbat válaszolnak meg, és ilyenkor nem feltétlenül egyértelmü, hogy egy válaszoló csoporttag melyik hozzászólással ért egyet stb. A nemlineáris társalgás nehezebben követhető, és megnehezíti az egyes témákban való nagyobb elmélyülést is, emiatt a leírt hozzászólások egy része nehezen értelmezhető lesz a csoporttagok és az elemző számára is. Gaiser (1997) meglátása szerint az online szövegalapú csoportoknál azért is nagyobb a felszínes társalgás esélye, mert a résztvevők már hozzászoktak az online csevegés felszínesebb és játékosabb jellegéhez, ezért nehézséget okozhat nekik, hogy ettől eltérő módon kommunikáljanak a csevegőfelületen szervezett fókuszcsoport során.

Mivel az emberek lassabban gépelnek, mint beszélnek, azonos ideig tartó szövegalapú és személyes fókuszcsoportos beszélgetés esetén a szövegalapú csoport kevesebb információt nyújt a kutatási témához. Schneider és szerzőtársai (2002) úgy találták, a szövegalapú szinkron csoportjaik során kevesebb szó „hangzott el” percenként, mint a személyes találkozások során. Nicholas és munkatársai (2010) krónikus beteg gyermekekkel kapcsolatos kutatásukban arra jutottak, hogy a személyes jelenléten alapuló fókuszcsoportok során nagyobb számú kódolható elemzési szempontot tudnak gyűjteni, mint az egy hétig tartó aszinkron online fókuszcsoport segítségével. A személyes találkozások során ugyanis részletesebben kifejtett válaszokat kaptak, ami gazdagabb és mélyebb adatgyújtést tett lehetővé, mint az aszinkron társalgás. Az aszinkron csoportokra jellemző kevesebb interakció (Graffigna - Bosio, 2006) és a résztvevők által adott kevesebb illusztratív eset és példa (Nicholas et al., 2010) csökkentheti az aszinkron csoport során gyüjtött adatok gazdagságát a személyes találkozáson alapuló fókuszcsoportos beszélgetéshez képest.

A kutatók szerint tehát az online kommunikáció mind a szinkron, mind az aszinkron csoportok esetében kevésbé gazdag adathalmazt eredményez, mint a szemtől szembeni csoportos beszélgetés (Schneider et al., 2002). „A médium gazdagsága azt jelenti, hogy az adott kommunikációs médium milyen mértékben bátorítja az azonnali interakciót és visszajelzést, és hogy lehetővé teszi a résztvevők számára, hogy többféle jelzésen keresztül, többféle érzékszervüket felhasználva kommunikáljanak" (Schneider et al., 2002, p. 33.). A szövegalapú társalgás során nem érzékelhetők a metakommunikációs jelzések, mint például a testmozdulatok. Greenbaum (1997) vélekedése szerint ez súlyos probléma: a kutató kiemeli a nonverbális kommunikáció fontosságát a hagyományos fókuszcsoportok során mind a moderátor, mind pedig az elemző számára. A testtartás, arckifejezés stb. utalhat arra, hogy egy résztvevő miért nem szól hozzá az adott témához: le- 
het, hogy félénk, de az is előfordulhat, hogy nem ért egyet a csoport többségének véleményével.

Az adatgazdagság és a kommunikációs médium gazdagsága mellett egy sor további tényezöt is figyelembe kell vennünk a szövegalapú fókuszcsoportok lehetséges hátulütőit vizsgálva. Ezek közé tartozik például, hogy csak olyan résztvevőket tudunk bevonni, akik rendelkeznek internetkapcsolattal, és képesek használni a csoport során alkalmazott csevegöfelületet, hogy a lassabban gépelő résztvevők hátrányban vannak a többiekhez képest, és kevesebbet tudnak hozzászólni (Franklin - Lowry, 2001; Walston - Lissitz, 2000), nem tudjuk, hogy a résztvevők aktívan figyelnek-e a csoportos interakcióra, vagy közben más dolgokkal is foglalkoznak (Grady, 2000; Greenbaum, 2000), a társalgás ideje alatt technikai problémák merülhetnek fel. Nehézséget jelenthet az is, hogy nem tudjuk pontosan, kik a résztvevők - lehetnek köztük olyanok is, akik nem azok, akinek mondják magukat, vagy nem rendelkeznek azokkal a tulajdonságokkal, amelyek alapján a csoportot össze kívánjuk állítani (Oringderff, 2004). A résztvevők öszszetüzésbe keveredhetnek. Felmerül az adatbiztonság kérdése abban az esetben, ha például illetéktelen személy hozzáfér a felvétel során rögzített anyaghoz, és képes lehet olyan személyeket azonosítani, akik anonimak kívántak maradni (Gaiser, 1997). Aszinkron csoportok esetében előfordulhat, hogy egyes résztvevők egy idő után kiszállnak a társalgásból (különösen, ha az hoszszabb ideig tart), vagy egyes időszakokban elfoglaltabbak, ezért kevésbé aktívak (Rezabek, 2000), másoknak pedig nehézséget jelenthet, hogy nem tudnak "arcot kötni a nevekhez" (Nicholas et al., 2010).

\section{Hogyan hidaljuk át a nehézségeket, hogyan érjünk el jobb eredményt?}

Amint a fenti részekben rámutattam, a szövegalapú csoportoknak számos hátulütője lehet. A legfőbb hiányosságok közé tartoznak az adatgazdagsággal és adatmélységgel kapcsolatos potenciális problémák. Cikkemben amellett fogok érvelni, hogy léteznek módszerek az adatgazdagság és adatmélység növelésére szövegalapú fókuszcsoportok esetében. Az is tény, hogy bizonyos csoportösszetételeknél potenciálisan kevésbé jelentkezik az adatgazdagság probléma - például szakértői csoport esetében. Továbbá, egyes kutatási célok szempontjából a kevésbé mély adatgyüjtés nem annyira problematikus (például ha csupán annyi a cél, hogy egy témában vélemények vagy gondolatok minél szélesebb körét gyüjtsük össze). Véleményem szerint tehát a szövegalapú fókuszcsoportok még annak ellenére is hasznos eszközt jelentenek, ha az audiovizuális online csoportok megszervezése egyre könynyebben megoldhatóvá válik. Figyelnünk kell azonban arra, hogy mi is a kitűzött kutatási cél, és hogyan szervezzük meg, illetve bonyolítjuk le a fókuszcsoportos interakciót.

$\mathrm{Az}$ online begépelős fókuszcsoportok egyes említett problémáin az alábbi módokon lehet segíteni:

Hosszabb válaszok elérése: számos megoldás alkalmazható a hosszabb válaszok és nagyobb adatgazdagság elérésére. A fókuszcsoport elején a kutató megkérheti a résztvevőket, hogy hosszabb válaszokat adjanak a csoport során, majd a későbbiekben belekérdezhet a hozzászólásokba további részletek iránt érdeklődve. Akár mintaválaszt is adhat az első kérdésre, hogy ezzel szemléltesse a kívánatos hosszúságot. Szinkron csoport esetében a moderátor hangsúlyozhatja a különbséget az online csevegés és az online fókuszcsoport között. Fontos, hogy a szervezők elözetesen teszteljék a csoportos beszélgetéshez használt felületet, és ellenőrizzék, hogy az nem nehezíti-e meg a hosszabb hozzászólásokat (egyes csevegőfelületek csak adott hosszúságú szöveget engednek meg, vagy nehezebb végigírni egy hosszabb szöveget, ha a gépelö közben nem látja a szöveg elejét stb.). Ha nehézkes hosszabb hozzászólásokat írni a kiválasztott felületre, érdemes másik csevegőalkalmazást keresni, vagy elgondolkodni a felmerülő probléma megoldásán. (Elegendő lehet akár az is, ha a résztvevőt megkérjük, hogy a megengedett karakterszám felhasználása után „...” jellel zárja a még be nem fejezett hozzászólását, majd újabb ,...” jelzéssel kezdje meg a következő hozzászólást. Ekkor azonban a két üzenet közt eltelt idő miatt előfordulhat, hogy más résztvevők hozzászólásai bekerülnek az egyes szövegrészek közé.) Szintén fontos, hogy ne kerüljön túl sok résztvevő egy szinkron csoportba, egyfelöl ugyanis így nehézkessé válhat a beszélgetés követése (Hughes - Lang, 2004), másrészt a csoport tagjai úgy érezhetik, hogy ki vannak zárva a társalgásból, ha túlságosan hosszú hozzászólásokat írnak. Tapasztalataim szerint többnyire az válik be legjobban, ha egy csoportban legföljebb hat résztvevő van. A kérdésvázlatban szereplő kérdéseknek emellett megfelelöen nyitottnak is kell lenniük. Ha a csoporttagok személyesen jelen vannak, elöfordulhat, hogy kevésbé nyitott kérdések is segítenek elmélyíteni a beszélgetést, mert a résztvevők további részleteket adnak hozzá a válaszaikhoz. Tapasztalatom szerint azonban az online szövegalapú beszélgetés során ez sokszor rövid válaszokat eredményez.

A válaszok hosszúsága szinkron csoportok esetében nagyobb problémának tünik, mint aszinkron helyzetekben (Burton - Goldsmith, 2002; Graffigna Bosio, 2006). Ha tehát célunk hosszabb válaszadásra bátorítani a résztvevőket, az aszinkron társalgás szervezése is jó megoldás lehet. Ekkor is érdemes azonban megemlíteni a résztvevőknek, hogy bátran adhatnak hosszabb leírásokat is. 
A résztvevők hozzászólásaira reagáló kérdések számának növelése: szinkron csoportok esetében hasznos, ha a csoport vezetője a központi kérdéseket elöre begépeli, amiket aztán csak be kell másolnia az online beszélgetésbe, így ezekkel nem szükséges a csoport ideje alatt időt töltenie, és több ideje marad spontán módon reagálni a beszélgetés során felmerülő hozzászólásokra. Szintén jó megoldás, ha egyszerre két moderátor irányítja a beszélgetést, egyértelmü szerepmegosztással (Walston - Lissitz, 2000). Egyikük a társalgást irányító kérdéseket teszi fel, a másik pedig figyelemmel követi a beszélgetést, reagál a hozzászólásokra, és irányítja a csoport dinamikáját - megfigyeli például, hogy melyik résztvevő hallgat hosszabb ideje, és hozzászólásra bátorítja stb. Ha csupán egy moderátor vezeti a csoportot, nem biztos, hogy elegendő ideje lesz egyszerre irányítani a beszélgetést és visszakérdezni a beérkezett hozzászólásokra.

A gondolatmenetek irányítása: a párhuzamosan futó gondolatmenetek (threading) nehezíthetik a kommunikációt. Érdemes lehet olyan csevegőfelületet választani, ami jelzi, ha valaki éppen hozzászólást gépel be, a moderátor így jobban átlátja, hogy mikor érdemes új témát felvetni, vagy megvárni, amíg a résztvevők befejezik az adott téma megvitatását. Szintén hasznos lehet, ha a moderátor felkéri a résztvevőket, jelezzék egyértelmüen, hogy melyik korábbi hozzászólásra reagálnak (amennyiben az ténylegesen egy korábbi hozzászólásra adott reakció). Megkönnyíti az egyértelmü jelölést, ha a hozzászólások számozva vannak.

A metakommunikáció hiányának áthidalása: a résztvevőket érdemes megkérni arra, hogy használjanak emotikonokat, illetve központozással vagy egyéb módon jelöljék a hozzászólásuk hangvételét. Sokan már egyébként is tisztában vannak ennek módszereivel (Terrel, 2011), de gyorsan zajló interakció esetén nem feltétlenül szakítanak időt az ilyen jelzések használatára, hacsak nem kérjük meg őket erre kifejezetten. A résztvevők életkora és más tényezők is befolyásolhatják, hogy mennyire lesz jellemző ez a fajta jelzésrendszer külön kérés nélkül.

Személyes információ megosztása: bizonyos esetekben, még ha meg is akarjuk örizni a csoporttagok anonimitását, hasznos lehet, ha a beszélgetés elején megosztunk a csoporttal kapcsolatban néhány alapvetö információt - ha például szexuális zaklatással kapcsolatos adatokat gyújtünk, és megoszthatjuk a csoporttal, hogy valamennyi résztvevő fiatal nő. Egyes megfigyelések szerint ugyanis ebben az esetben a résztvevők könnyebben megnyílnak bizonyos témákkal kapcsolatban, mintha semmiféle információjuk nem lenne a csoport összetételéröl (Taylor - McDonald, 2002).

Arcot kötni a nevekhez: ha a kutatási cél szempontjából nem szükséges megőrizni a csoporttagok anonimitását, érdemes lehet megkérni a tagokat, hogy írjanak rövid bemutatkozást, és küldjenek magukról képet is a többi résztvevőnek. A résztvevők így jobban kötődnek a csoporthoz, ami a tagok kiesésének aszinkron csoportok esetén jellemző nagyobb kockázatát is mérsékli.

A gépelés beszédhez viszonyitott lassúságának problémája: el kell döntenünk, hogy mi a fontosabb a kutatás szempontjából: kevesebb téma mélyebb megvitatása, vagy témák minél szélesebb körének felvetése. Ha nagyobb adatmélységre törekszünk, szinkron online csoport esetében érdemes kevesebb kérdést megfogalmazni, mint személyesen jelen lévő csoport esetében tennénk, mivel a résztvevők lassabban gépelnek, mint ahogy beszélni tudnak. Megtehetjük, hogy csak olyan csoporttagokat válogatunk össze, akik egy bizonyos sebességgel gépelnek, a nagyon lassan gépelőket pedig inkább kihagyjuk a csoportból (vagy ezeket a szereplőket inkább aszinkron fókuszcsoportba vonjuk be). A telefonon vagy tableten gépelő résztvevők válaszadása lassabb lehet, mint a számítógépről hozzászólóké. Érdemes arra bíztatni a résztvevőket, hogy olyan eszközt válasszanak, ami viszonylag gyors gépelést enged meg.

Az interakciók számának növelése: személyes fókuszcsoportos beszélgetés során általában elegendő a csoport elején elmondani, hogy olyan beszélgetést szeretnénk kezdeményezni, amelyben a csoporttagok reagálnak egymás hozzászólásaira, és az interakciók száma többnyire külön bátorítás nélkül is megfelelö. A szövegalapú csoportokban azonban szükséges lehet ezt a szempontot a beszélgetés későbbi fázisaiban is megemlíteni. Előfordulhat, hogy felteszünk egy kérdést, amire a csoporttagok válaszolnak, miközben nem reagálnak egymás válaszaira - különösen, ha szimultán gépelték be hozzászólásaikat. Ilyenkor érdemes lehet megkérni a résztvevőket, hogy gondolják végig a feltett kérdés egy-egy olyan aspektusát, amit valamelyik válaszoló vetett fel.

A téma minél teljesebb körü megvitatása: a szélesebb körü, részletekbe jobban belemenő fókuszcsoportos beszélgetések eléréséhez jó stratégia lehet, ha egyazon kutatásban kombináljuk a szinkron és az aszinkron online fókuszcsoportos módszert (Graffigna - Bosio, 2006, p. 70.), és csoporttagok mindkét csoportban részt vesznek. A résztvevőket felkérhetjük például arra, hogy először szinkron beszélgetésben vegyenek részt, majd pedig a felmerült témákban aszinkron társalgás során jobban elmélyedhetnek, miközben itt viszszatérhetünk olyan gondolatmenetekre is, amik hamar elhaltak, nem voltak teljesen világosak stb. Az aszinkron csoportot megkezdhetjük a szinkron fókuszcsoport indítása előtt is, majd folytathatjuk annak befejeztével is. Az aszinkron helyzet ebben az esetben hozzásegít- 
heti a csoporttagokat ahhoz, hogy megismerjék egymást és a kutatási problémát. Graffigna és Bosio (2006) ezt a megoldást alkalmazták egy érzékeny terület (HIV/ AIDS) vizsgálatánál, és úgy találták, hogy „,a két kommunikációs mechanizmus kombinációja lehetővé tette a két különböző helyzetben rejlö lehetőségek integrációját" (Graffigna - Bosio, 2006, p. 66.). A fórumtípusú beszélgetések hosszabb és megfontoltabb válaszadást, elvontabb és racionálisabb gondolatmeneteket eredményeztek, míg a csevegő helyzetben nagyobb hangsúlyt kaptak a személyes tapasztalatok. Figyelemre méltó módon a szinkron és aszinkron fókuszcsoportos módszerek kombinálása esetén a szinkron beszélgetések „jobban szervezettebbek” és „kevésbé fragmentáltak” voltak, mint amikor a kutatók csak csevegés típusú kommunikációra hagyatkoztak anélkül, hogy a csoporttagok az aszinkron csoport segítségével előzetesen megismerkedhettek volna egymással és a témával. A kutatók tehát arra a következtetésre jutottak, hogy a két online módszer együttes alkalmazása különösen hasznos azokban az esetekben, ,amikor egy jelenség széles körü és többdimenziós feltárása a cél" (Graffigna - Bosio, 2006, p. 70.). A kombinált módszer hátránya, hogy több időt és szervezést igényel. Olyan résztvevőket kell bevonni, akik az egyszeri beszélgetés mellett hajlandók az aszinkron részvételre is időt fordítani a kutatók által kijelölt időszakban. Emellett a kétféle kommunikációs módszer használata miatt az elemzés folyamata is összetettebb lesz.

Teljesebbé teheti kutatásunkat, ha videók és képek feltöltésére is kérjük a résztvevőket, akkor is, ha alapvetően/vagy részben szövegalapú a kutatásunk. Egy példa: egy piackutatás azt vizsgálta, az italfogyasztás hova illeszkedik aktív életstílus esetén. Aszinkron csoportjukban lehetőség volt szövegbeírásokra. Ezen kívül ide kérték még olyan fotók feltöltését is, amelyek az italok tárolási helyeit mutatják, valamint videókat italfogyasztási élményekről (Schmaltz, 2015). Ezek eredményeképpen nagyon sokféle információt kaptak a vizsgált jelenséghez kapcsolódóan. Nem kellett elmenniük az otthonokba, italfogyasztási helyszínekre, mégis beleláthattak, hogy ott mik történnek.

Egyik típusa a videók és képek feltöltését is lehetővé tevő csoportoknak, a különféle közösségi oldalakon végzett fókuszcsoportok. Ezeknek több egyéb előnye is van azon felül, hogy teljesebbé tehetik az eredményekből kirajzolódó képet. Egyrészt itt ismerős felülettel találkozhatnak a résztvevők (ha egyazon felületen végezzük a kutatást, mint ahonnan toborozzuk őket), másrészt a csak szövegalapú chat felületeket már sokan elavultnak tartják, ezek a felületek jobban tükrözik a mostani tipikus interneten előforduló interakciókat. Ráadásul, ha nincs szükség a kutatáshoz anonimitásra, itt akkor segítheti a kommunikációt, hogy arcot tudnak kapcsolni a nevekhez a résztvevők.

Megfontolandó az is, hogy jobban kiaknázhatjuk az online kvalitatív kutatások teljes potenciálját, ha több módszert alkalmazó kutatást végzünk, akár egy netnográfiai (Dörnyei - Mitev, 2010) kutatás keretében, amelyen belül az online fókuszcsoport csak egyike a végzett kutatási tevékenységeknek, és emellett például az interneten eleve hozzáférhetö különféle tartalmak (fórumok, blogok, Twitter bejegyzések, nyilvános Facebook-oldalak stb.) szövegelemzésére is sor kerül.

A csoporttagok kiesésének kockázata: a hosszabb ideig tartó aszinkron csoportokban nagyobb problémát jelent a résztvevők kiesésének kockázata. Meg kell tehát fontolni, hogy ne túl hosszú ideig tartson az aszinkron csoport. Esetenként érdemes lehet ellenőrizni, hogy van-e olyan résztvevő, aki már hosszabb ideje nem szólt hozzá a témához, e-mailben felkeresni, rákérdezni a hallgatás okára, és aktívabb részvételre bátorítani. Egy másik lehetséges stratégia eleve viszonylag sok résztvevővel indítani a csoportot, ilyenkor ugyanis a résztvevők száma akkor sem lesz túl kicsi, ha időközben több tag is elhagyja a csoportot.

A technikai problémák kezelése: mindenképp szükséges használat előtt tesztelni a fókuszcsoportos beszélgetésre használt felületet, hogy felmérhessük az esetlegesen jelentkező technikai problémákat. Érdemes több különböző időpontban tesztelni, ugyanis az ingyenesen használható csevegőfelületek az internethasználat csúcsidőszakaiban (pl. péntek este) erősen túlterheltek lehetnek. Még előzetes tesztelés esetén is előfordulhatnak technikai problémák a csoport menete alatt, egy-egy résztvevő például átmenetileg kieshet a beszélgetésböl (pl. gyenge internetkapcsolat miatt), így fel kell készülnünk arra is, hogy a menet közben jelentkező technikai hibákat kezeljük. Hasznos, ha a szinkron beszélgetés idején kapcsolatba tudnak a résztvevők lépni olyasvalakivel, aki szükség esetén számítástechnikai segítséget nyújt (ez akkor is jó, ha végül nem sikerül megoldani a problémát, ugyanis így nem a moderátornak kell ezzel időt töltenie, miközben a társalgásból kieső személy sem érzi úgy, hogy magára hagyják a problémájával).

Az adatbiztonság és anonimitás kérdése: a biztonsági problémák elkerülését segíti, ha jelszóval védett felületen folytatjuk a csoportos beszélgetést. A résztvevők anonimek maradnak, ha a csevegőszobába saját maguk által választott felhasználónéven jelentkeznek be.

Összegzésként elmondható, hogy óriási különbségek lehetnek a szövegalapú fókuszcsoportok esetében az adatgazdagságban és a minőségben: ezekből a szempontokból a módszer lényegesen hatékonyabbá tehetö a cikkben megfogalmazott egyes eszközök alkalmazásával. 


\section{Jegyzetek}

${ }^{1}$ A cikk az OTKA/NKI 108981 számú kutatása keretén belül készült. A szerző munkáját a Magyar Tudományos Akadémia Bolyai János Kutatási Ösztöndíjjal támogatja.

${ }^{2}$ A szerző szisztematikus Google Scholar keresése alapján (2016. február 15.). A legtöbb találat egészségügyi kutatás volt, viszonylag kevés kutatás fordult elő, amely ezen a terülten kívülre esett.

${ }^{3}$ A Piackutatási blog 2010-ben külföldi és hazai piackutatók, fókuszcsoportos szakemberek álláspontját mutatta be a kérdéskörben „Miért nem vált eddig népszerüvé az online fókuszcsoport” címmel (Forecast Research, 2010a, 2010b).

${ }^{4}$ A Secondlife egy virtuális világ, a felhasználói kiválaszthatnak saját maguknak egy vizuális megjelenítést (avatart) és utána avatarjukon keresztül interakcióba léphetnek más avatarokkal (http://secondlife.com/).

\section{Felhasznált irodalom}

Abrams, K. - Wang, Z. - Song, Y.J. - Galindo-Gonzalez, S. (2015): Data Richness Trade-Offs Between Face-to-Face, Online Audiovisual, and Online TextOnly Focus Groups. Social Science Computer Review, 33(1), 80-96. o. doi: 10.1177/0894439313519733

Bodoky T. (2007): „Nincs tévém, nem olvasok papírújságot" Médiakutató 2007 nyár, http://www.mediakutato.hu/cikk/2007_02_nyar/06_nincs_tevem, Letöltve: 2015 . november 13 .

Burton, L. - Goldsmith, D. (2002): The Medium is the Message: Using online focus groups to study online learning. A Presentation for the Association for Intuitional Research (2002. június 4.). Toronto, Ontario, Canada. http://www.ctdlc.org/Evaluation/ mediumpaper.pdf, Letöltve: 2015. november 13.

Cook, K. - Jack, S. - Siden, H. - Thabane, L. - Brow$n e, G$. (2014): Innovations in Research with Medically Fragile Populations: Using Bulletin Board Focus Groups. The Qualitative Report, 19(39), 1-12. o. http://nsuworks.nova.edu/tqr/vol19/iss39/1, Letöltve: 2015. november 13.

Dörnyei K. - Mitev A. (2010): Netnográfia, avagy on-line karosszék-etnográfia a marketingkutatásban. Vezetéstudomány. XLI. évf. 2010. 4. szám

Franklin, K. K. - Lowry, C. (2001): Computer-mediated focus group sessions: naturalistic inquiry in a networked environment. Qualitative Research, 1(2), 169-184. o. doi: 10.1177/146879410100100204

Forecast Research (2010a): Miért nem vált eddig népszerủvé az online fókuszcsoport? (1. rész - külföldi szakértők). http://piackutatas.blog.hu/2010/01/04/ miert_nem_valt_eddig_nepszeruve_az_online_fokuszcsoport_1_resz_kulfoldi_szakertok, Letöltve: 2015. november 13.

Forecast Research (2010b): Miért nem vált eddig népszerüvé az online fókuszcsoport? (2. rész - hazai szakértők).

http://piackutatas.blog.hu/2010/01/05/miert_nem_valt_ eddig_nepszeruve_az_online_fokuszcsoport_2 resz_hazai_szakertok, Letöltve: 2015 . november $1 \overline{3}$.
Fox, E. - Morris, M. - Rumsey, N. (2007): Doing Synchronous Online Focus Groups with Young People: Methodological Reflections. Qualitative Health Research, 17(4), 539-547. o. doi: $10.1177 / 1049732306298754$

Gaiser, T. J. (1997): Conducting On-Line Focus Groups. A Methodological Discussion. Social Science Computer Review, 15(2), 135-144. o.

Grady, H.W. (2000): Virtual focus group: a methodological assessment. Paper presented at the Midwest Association for Public Opinion Research Annual Convention, Chicago. 2000 november.

Graffigna, G. - Bosio, A.C. (2006): The Influence of Setting on Findings Produced in Qualitative Health Research: A Comparison between Face-to-Face and Online Discussion Groups about HIV/AIDS. International Journal of Qualitative Methods. 5(3), 5576. 0.

Greenbaum, T. L. (1997): Internet Focus Groups: An Oxymoron. Marketing News, 35-36. o. 1997. március 3. http://www.groupsplus.com/pages/oxymoron. htm, Letöltve: 2015. november 13.

Greenbaum, T. L. (2000): Focus Groups Vs. Online Clients: Weigh benefits, liabilities of research types before buying. Advertising Age, február14.

Heltzel, N. (2014): Cell Phone Cyberbullying's Impact on Victims' Attendance, Academics, and Social and Personal Life in School: A Phenomenological Qualitative Study. Doctoral Dissertations and Projects. Paper 893. http://digitalcommons.liberty.edu/doctoral/893, Letöltve: 2015. november 13.

Herendy Cs. (2009): Weboldal-fejlesztés: innovatív és hagyományos módszerek II. Médiakutató 2009 tavasz

http://www.mediakutato.hu/cikk/2009_01_tavasz/04_ weboldal_fejlesztes, Letöltve: 2015. november 13.

Ho, S. S. - McLeod, D. M. (2008): Social-Psychological Influences on Opinion Expression in $\mathrm{Fa}-$ ce-to-Face and Computer-Mediated Communication. Communication Research, 35(2), 190-207. o. doi: $10.1177 / 0093650207313159$

Hughes, J. - Lang, K. L. (2004): Issues in Online Focus Groups: Lessons Learned from an Empirical Study of Peer-to-Peer Filesharing System Users. Electronic Journal of Business Research Methods, 2(2), 95-110. o. http://www.ejbrm.com/vol2/v2-i2/vol2issue2-art5-hughes.pdf, Letöltve: 2015. november 13.

Index (2006): Titkos gondolatokra is fényt derít az online fókuszcsoport, http://index.hu/tudomany/onlinefok053/, Letöltve: 2015. június 2.

Lijadi, A. A. - G. J. van Schalkwyk (2015): Online Facebook Focus Group Research of Hard-to-Reach Participants. International Journal of Qua- 
litative Methods, 14(5), 2015 december: 1-9. o. doi:10.1177/1609406915621383

Link, A., - Dinsmore, S. (2014): Online Focus Groups: Selecting a Platform. 2014. december 7. http://www. academia.edu/2064385/Online_Focus_Groups_Selecting_a_Platform, Letöltve: 2015 . november $\overline{1}$ 3.

Maulana, A. E. (2002): Consumer Misconceptions of FMCG's Brand-Sites: An Exploratory Study Using Virtual Focus Groups. ANZMAC 2002 Conference Proceedings. http://130.195.95.71:8081/WWW/ ANZMAC2002/papers/pdfs/p345_maulana.pdf , Letöltve: 2015. november 13.

Nicholas, D.B. - Lach L. - King, G. - Scott, M. - Boydell, K. - Sawatzky, B.J. - Resiman, J. - Schippel, E. -Young, N.L. (2010): Contrasting Internet and Face-to-Face Focus Groups for Children with Chronic Health Conditions: Outcomes and Participant Experiences. International Journal of Qualitative Methods, 9 (1), 106-121. o.

Newby, R. - Soutar, G. - Watson, J. (2003): Comparing Traditional Focus Groups with a Group Support Systems (GSS) Approach for Use in SME Research. International Small Business Journal, 21(4), 421-433. o.

Oringderff, J. (2004): "My Way": Piloting an online focus group. International Journal of Qualitative Methods, 3(3), 69-75. o. https://ejournals.library.ualberta.ca/index.php/IJQM/article/view/4466/3791, Letöltve: 2015. november 13.

Rezabek, $R$. (2000): Online focus groups: Electronic discussions for research. Forum Qualitative Sozialforschung / Forum: Qualitative Social Research, 1(1), Article 18. http://nbn-resolving.de/urn:nbn:de:0114-fqs0001185, Letöltve: 2015. november 13.

Schmaltz, J. (2015): Online focus groups - How do they work? Videó az interneten. https://www.youtube.com/watch? $=9 j$ jh 5 hlfX28w，Letöltve: 2015. november 3.

Síklaki I. (2006): Az online kvalitatív közvélemény- és piackutatás módszertani kérdései. Jel-Kép, 2. sz., 59-73. o.
Stewart, K. - Williams, M. (2005): Researching online populations: the use of online focus groups for social research. Qualitative Research, 5(4), 395-416. o. doi: $10.1177 / 1468794105056916$

Schneider, S. J. - Kerwin, J. - Frechtling, J. - Vivari, B. A. (2002): Characteristics of the Discussion in Online and Face-to-Face Focus Groups. Social Science Computer Review, 20(1), 31-42. o. doi: 10.1177/089443930202000104

Underhill, C. - Olmsted, M. C. (2003): An Experimental Comparison of Computer Mediated and Face-to-Face Focus Groups. Social Science Computer Review, 21(4), 506-512. o.

Tatar, J. (2008): Focus groups on Second Life. www. qrca.org/associations/6379/files/SecondLifeFINAL. doc, Letöltve: 2015. november 3.

Taylor, J. - MacDonald, J. (2002): The Effects of Asynchronous Computer-Mediated Group Interaction on Group Processes. Social Science Computer Review, 20(3), 260-274. o.

Terrell, S. R. (2011): Face-to-Face in Writing: My First Attempt at Conducting a Text-based Online Focus Group. The Qualitative Report, 16(1), 286-291. o. http://nsuworks.nova.edu/tqr/vol16/iss1/19, Letöltve: 2015. november 13 .

Turney, L. - Pocknee, C. (2005): Virtual focus groups: New frontiers in research. International Journal of Qualitative Methods, 4(2), http://ualberta.ca/ ijqm/ backissues/4_2/pdf/turney.pdf, Letöltve: 2015. november 13 .

Vicsek L. (2006): Fókuszcsoport. Budapest: Osiris Kiadó

Walston, J. T. - Lissitz, R. W. (2000): Computer-Mediated Focus Groups. Evaluation Review, 24(5), 457483. o. doi: $10.1177 / 0193841 X 0002400502$

Williams, M. (2007): Policing and Cybersociety: The Maturation of Regulation within an Online Community, Policing and Society, 17(1), 59-82 o. doi: 10.1080/10439460601124858 